This PDF is a selection from a published volume from the National Bureau of Economic Research

Volume Title: China's Growing Role in World Trade

Volume Author/Editor: Robert C. Feenstra and Shang-Jin Wei, editors

Volume Publisher: University of Chicago Press

Volume ISBN: 0-226-23971-3

Volume URL: http://www.nber.org/books/feen07-1

Conference Date: August 3-4, 2007

Publication Date: March 2010

Chapter Title: China's Outward Foreign Direct Investment

Chapter Author: Leonard K. Cheng, Zihui Ma

Chapter URL: http://www.nber.org/chapters/c10475

Chapter pages in book: (545 - 578) 


\title{
China's Outward \\ Foreign Direct Investment
}

\author{
Leonard K. Cheng and Zihui Ma
}

\subsection{Introduction}

China has achieved remarkable success in attracting foreign direct investment (FDI) since the early 1990s. It became the largest recipient of FDI among developing economies for the first time in 1993 and then became one of the top three recipients of FDI in the world in 2003 to 2005 and number four in 2006 based on preliminary estimates. ${ }^{1}$ Perhaps as a reflection of this success, there are many papers written on the various aspects of China's

Leonard K. Cheng is a Chair Professor of economics and Dean of Business and Management at the Hong Kong University of Science and Technology. Zihui Ma is a lecturer of international economics at Renmin University of China.

We would like to thank Lee Branstetter, Robert Feenstra, Martin Feldstein, Nicholas Lardy, Shang-Jin Wei, and other participants of the National Bureau of Economic Research's conference on China's Growing Role in World Trade for their encouragement and suggestions. We would also like to thank Bih Jane Liu, Chao-Cheng Mai, and participants at a conference on Studies of China's Mode of Economic Development held at Academia Sinica in Taipei on June 28-29, 2007, and to seminar participants at the Indian Statistical Institute for their comments on earlier drafts of this chapter. Finally, we are grateful to Mayumi Fukumoto for her assistance in providing Japan's foreign direct investment (FDI) data, and to Jae Nahm for his assistance in providing South Korea's FDI data.

1. According to UNCTAD's World Investment Report 2004 (annex table B.1, 367 and 370), in 2003, China's inward FDI of US\$53.5 billion ranked number one, before both France (US\$ 47 billion) and the United States (US\$29.8 billion), the second and third largest recipients of FDI in that year. However, in the World Investment Report 2005 (annex table B.1, 303), the U.S. figure for 2003 was revised to become US $\$ 56.8$ billion, implying that China would rank number two in that year after the United States. In 2004, China's inward FDI (US\$60.6 billion) ranked number three after the United States (US\$95.9 billion) and the United Kingdom (US\$78.4 billion). According to UNCTAD Investment Brief Number 1 2007, China was ranked number two (after the United States) in 2004, number three (after the United Kingdom and the United States) in 2005, and number four (after the United States, the United Kingdom, and France) in 2006. The 2006 data were preliminary estimates.) 
inward FDI. In contrast, China's outward FDI up to now is small and, thus, not as much systematic research has been carried out.

Nevertheless, as China is rapidly integrating with the global economy, its outward FDI has picked up in recent years. More important, perhaps, several major acquisition efforts have brought media attention to China as a source of FDI. Among them, Lenovo's acquisition of IBM PC announced in December 2004 could arguably be the most eye-catching example of these efforts. The other highly visible cases included the electronic appliance manufacturer TCL's acquisition of France's Thomson Electronics in 2004, white-goods manufacturer Haier's building of plants in the United States since the late 1990s, China's third-largest oil producer China National Offshore Oil Corporation's (CNOOC) failed attempt to acquire U.S. oil company UNOCAL in 2005, and Nanjing Automotive's success in acquiring the United Kingdom's MG Rover Group in $2005 .^{2}$ The energy crunch in 2006 also witnessed numerous stories about China's effort to invest in oil companies in the world, in particular in Russia, Central Asia, and Africa, giving an impression that resource grabbing was a key driving force behind China's outward FDI.

\subsubsection{Background}

A description of China's outward FDI from 1979 to 1996 can be found in Cai (1999). The country's annual FDI outflow grew from virtually zero in 1979, when China embarked upon its open-door policy, to US\$628 million in 1985, and to US\$913 million in 1991, before shooting up to US\$4 billion in 1992, the year in which China's paramount leader Deng Xiaoping made an important tour to South China to reaffirm China's commitment to its reform and open-door policy in the aftermath of the Tiananmen crackdown in 1989.

By the end of 1996, China's total stock of FDI outflows was over US\$18 billion. It surpassed South Korea (US\$13.8 billion) and Brazil (US\$7.4 billion) to move up to the number four position among developing economies, behind Hong Kong (US\$112 billion), Singapore (US\$37 billion), and Taiwan (US\$27 billion; Cai, 1999, 861).

In the period of 1979 to 1993, almost two-thirds of China's FDI was made in Asia, including 61 percent in Hong Kong and Macau. The other regions in descending order were North America (15 percent), Oceania (8 percent), Central and Eastern Europe (5 percent), Africa (2 percent), Latin America (2 percent), and Western Europe (2 percent; Cai 1999, p. 864). Nearly 60 percent of China's FDI up to 1994 was in the services sector, mainly to service and promote its exports. The remaining FDI was in natural resources

2. Even though Shanghai Automotive started to have some cooperative arrangements with MG Rover involving intellectual property rights, in the end, the British automaker was sold to Nanjing Automotive after the former went into bankruptcy (http://www.zydg.net/magazine/ article/1671-4725/2005/16/222961.html). 
(25 percent) and manufacturing (15 percent, mainly in textiles and clothing and other labor-intensive industries, located primarily in Africa, Asia, and the Pacific.

The FDI statistics used by Cai were provided by the United Nations Conference on Trade and Development (UNCTAD) and collected by the International Monetary Fund (IMF) based on balance-of-payments accounting. Relative to the UNCTAD statistics, outward FDI statistics provided occasionally by the Ministry of Commerce (MOFCOM) and its predecessor MOFTEC up to 2002 represented serious underestimates. ${ }^{3}$ Among other things, MOFCOM excluded investment projects not screened and approved by relevant government agencies and did not include investment made after the projects' initial approval, such as the plough back of retained earnings. However, as part of China's policy of encouraging its firms to go overseas, from 2002 onward, MOFCOM's FDI statistics have been collected in accordance with Organization for Economic Cooperation and Development (OECD) definitions and IMF's balance-of-payments guidelines. Thus, if there were still discrepancies between MOFCOM and UNCTAD's FDI statistics, the discrepancies from 2003 onward should be smaller than before.

Hong and Sun (2004), also using UNCTAD's FDI statistics, reported that the stock of China's outward FDI reached about US $\$ 36$ billion by end the of 2002, ranked number six among 118 developing economies. They found that the growth of China's aggregate FDI outflows during 1988 to 2002 were quite similar to those of South Korea during the same period and to Japan's outflows in the period of 1968 to 1982 . The sector composition of China's FDI, with 40 to 50 percent of shares in the nontrade category, was similar to that of South Korea in the 1980s and that of Japan in the 1960s and 1970s.

Hong and Sun found that the motives, destination, financing, and mode of entry of Chinese investors had undergone changes in the 1990s. For example, even though natural resources were still an important motive, in the late 1990s, increasingly more Chinese firms used FDI to acquire advanced foreign technologies and managerial skills, which had the effect of increasing their investment in the United States. Also, from 1992 to 2001, Chinese firms increasingly exploited and further developed their comparative advantages in Asia, Africa, and Latin America. In 1997 to 2001, Africa, with a share of 24.1 percent, became the second largest regional destination of Chinese FDI outflows, only after Asia. Since the mid-1990s, more and more Chinese firms used listing in overseas stock markets (Hong Kong and New York) to raise equity capital and to enhance their international reputation. What they found most striking, however, was that mergers and acquisitions gradually became the main form of investing overseas.

3. As indicated in Cai $(1999,857)$, some argued that the actual stock of FDI outflows from the beginning of China's open-door policy to the late 1990s were between US\$80 billion and US\$100 billion, even though only US\$15 billion was officially approved. 


\subsubsection{Related Literature}

Because China is a developing economy and until the last few years had been generally short of capital and foreign exchange, its outward FDI requires some explanations. Cai (1999) identified four motives for Chinese FDI: (a) market; (b) natural resources; (c) technology and managerial skills; and (d) financial capital. These motives were later augmented by other researchers. For instance, Deng (2004) identified two additional motives: (e) strategic assets (e.g., brands, marketing networks), and (f) diversification. Clearly, because China was itself a low-cost production base, cost minimization was not a major motivation of Chinese FDI overseas.

Alternative routes taken by China and its national firms to acquire the preceding assets and resources have received attention in fields of international business and politics. For example, Child and Rodrigues (2005), on the basis of case studies, examined the pros and cons of three alternative routes taken by Chinese firms in seeking technological and brand assets: (a) acting as an original equipment manufacturing (OEM) firm and forming joint ventures with foreign firms; (b) mergers with and acquisitions of foreign firms; and (c) organic international expansion (i.e., green field investment overseas).

As a world factory, China will become increasingly more dependent on the global supply of raw materials and energy, and China's FDI in natural resources seems to have captured the world's imagination. There were many reports of billion dollar deals in 2006 and 2007 involving oil-producing African countries (e.g., Taylor 2009), central Asian countries (e.g., International Herald Tribune, October 27, 2006), and elsewhere. This impression of foreign investment activities in natural resources indeed found support in the FDI statistics, which shows that China made US\$8.54 billion in 2006 in "mining, quarrying, and petroleum," accounting for 40.4 percent of the country's total FDI in that year. ${ }^{4}$ However, the gap between official statistics and figures found in news reports appears to be big.

4. The figures quoted in news reports would not necessarily result in official FDI statistics because the former often included the total value of planned investment over many years into the future, and some of the planned investment might not take place as planned. Let's use two examples to compare the FDI statistics as reported in the 2005 Statistical Bulletin issued by China's Ministry of Commerce against the statistics quoted in the newspaper reports. As an example, the total stock of Chinese FDI in Algeria by the end of 2005 as reported in the Bulletin was US\$171 million, much less than the value of a single deal involving China National Petroleum Corporation (CNPC) as reported in Taylor (2009, 45): "In 2003 CNPC purchased a number of Algerian refineries for $\$ 350$ million and signed a deal to explore for oil in two blocks." What could be the explanations of the big difference in FDI statistics besides misreporting on either side or on both sides? Did CNPC take a long time to implement its deal so that by the end of 2005 only a fraction of the transacted amount was actually invested? Or did CNPC sell part or all of its interests before the end of 2005? Or was part or all of the investment considered portfolio investment and, thus, not included as direct investment? As another example, according to Taylor $(2009,50)$, China's investment in Sudan was estimated at $\$ 4$ billion. However, by the end of 2005, China's official statistics showed only a stock of US\$352 million, which was even less than Taylor's report of US\$600 million that Sinopec and CNPC jointly paid in November 2005 for drilling rights to an oilfield in the country. 
As a reflection of Chinese effort to secure the supply of raw materials and energy for its national economy, there is a literature on "resource diplomacy," which was, according to Zweig (2006, 2), defined as "diplomatic activity designed to enhance a nation's access to resources and its energy security." While the first and foremost resource sought after by China is oil, the country is also in great demand for other minerals such as copper, bauxite, uranium, aluminum, manganese, iron ore, and so on (see, e.g., Taylor 2009, 37). ${ }^{5}$ As pointed out by Taylor, "the strategy chosen is basically to acquire foreign energy resources via long-term contracts as well as purchasing overseas assets in the energy industry" (37). These strategic choices also apply to other key natural resources. After a systematic analysis of China's FDI statistics, we shall highlight its investment in the energy sector.

Using statistics on approved outward FDI as published in the Almanac of China's Foreign Economic Relations and Trade from 1991 to 2005, Cheung and Qian (2007) found that, consistent with the earlier literature, China's investment was motivated by both market-seeking and resource-seeking. However, they did not find substantial evidence that its investment in African and oil-producing countries was mainly for their natural resources. In addition, they found that China's international reserves and exports to developing countries tended to promote FDI; the latter finding suggests that some investment in developing countries could be either for the purpose of facilitating or complementing exports.

Researchers in the fields of international business and politics recognize the importance of the role of the Chinese government in China's outward FDI. This point would not be hard to appreciate because, as we shall see in the following, until now the lion's share of China's outward FDI has been made by firms that have close relationships to various levels of government. Moreover, overseas investment by Chinese private firms requires government approval. Partly as a result of the perceived need to secure key natural resources and technologies through ownership, and partly due to the awareness that Chinese firms must compete in the global arena when foreign firms intensify their entry into the domestic market, China started to initiate a policy to encourage its national firms to "go overseas" in 2001. The government not only relaxed the approval process of outward FDI, but also provided incentives for FDI in target industries and recipient countries. This policy shift toward outward FDI will be further discussed in the following.

Stimulated by international attention on some successes and failed attempts of buyout by Chinese multinational firms, Antkiewicz and Whalley (2006) discussed three policy issues about cross-border mergers and acquisitions. They were (a) government subsidization of cross-border mergers and acquisitions; (b) transparency of the acquiring firms; and (c) national

5. According to Taylor $(2009,39)$, China surpassed Japan in 2003 to become the world's second largest user of oil products after the U.S. 
security concerns of OECD countries whose firms are the targets of foreign buyouts.

The purpose of this paper is fourfold: (a) to provide a brief introduction to China's "go overseas" policy; (b) to provide a systematic analysis of the size and composition of China's outward FDI in 2003 to 2006, the period over which such data are available from China's Ministry of Commerce; (c) to uncover the determinants of the amounts of China's outward FDI to the host economies, and (d) to shed light on China's past and future outward FDI by analyzing the determinants of the amounts of the outward FDI of the world's source economies and those of Japan and South Korea to yield an East Asian perspective.

The paper is organized as follows. The next section describes China's "go overseas" policy first proclaimed in 2001, to be followed by section 14.3, which analyzes the pattern of China's outward FDI in 2003 to 2006, including the total amounts, sector composition, geographical distribution, and the identity of investing firms. Section 14.4 discusses China's foreign investment in the energy sector, while section 14.5 attempts to uncover the determinants of the amounts of China's outward FDI in the host economies with the help of gravity equation regression analysis. Section 14.6 examines the determinants of the total amounts of outward FDI of the world's source economies, with a particular focus on Japan and South Korea's experience, to shed light on China's past and future FDI. Section 14.7 compares China sector composition and geographical distribution of FDI against those of Japan and South Korea. The final section summarizes and indicates directions for further research.

\subsection{China's “Go Overseas" Policy toward Outward FDI}

The Chinese government first proposed Chinese firms to "go overseas" ("zouchuqu" literally means "go out" but may be taken to mean "go global" as some authors have done) in 2001 in its 10th Five-Year plan. In the sixth national congress of the China Communist Party (CCP) in 2002, President Jiang Zeming proclaimed the go overseas policy, which covers FDI, the undertaking of foreign construction and engineering projects, and the export of Chinese employment or labor services. Due to lack of publicly available information, however, it is difficult to provide a complete catalogue of specific measures that have been introduced under the go overseas policy. It is known that in the initial stage of the policy's introduction, policy measures were mainly in the form of relaxation of restrictions on investment overseas, including the vetting and approval of such investment, plus some minor financial support.

In January 2004, the Ministry of Commerce, the Ministry of Finance, and the State Administration of Foreign Exchange promulgated a series of measures that aimed to promote Chinese investment overseas in goods pro- 
cessing (including export processing). Among other things, the vetting and approval of investment of US $\$ 3$ million or less were delegated to provincial level government agencies, while project proposal and feasibility study no longer required approval. In addition, a "Central Foreign Trade Development Fund" of RMB2.3 billion was set up to support investment in overseas processing activities, and both the scope and proportion of interest payment subsidy were increased. For nonfinance, nonprocessing FDI, the approval of foreign investment projects was delegated to local authorities at twelve coastal Chinese cities.

In addition to policies in support of FDI, funds were also set up to support Chinese firms in bidding for foreign construction or engineering projects, in the form of subsidy for project finance and insurance.

To promote Chinese firms to go overseas, a wide variety of services was provided by the government, ranging from promoting national firms during official visits by government officials and state leaders, to incorporating business negotiations into intergovernmental cooperation frameworks, to building databases on investment environment and opportunities in specific host countries, to providing consultancy services to Chinese firms that consider overseas investment. ${ }^{6}$ Furthermore, in addition to the central government and its overseas offices, local governments were also involved in supporting investment overseas. Government agencies worked closely with investing firms and industry associations to promote the investing firms' interests. Both policy banks and commercial banks were involved in assisting the finance of overseas activities, including FDI.

A regular mechanism was set up by the Ministry of Commerce in association with All-China Federation of Industry and Commerce as early as May 2004 to encourage private firms to go overseas, and a draft document that surfaced in 2006 called for stronger support for non-state-owned firms in the areas of taxation, finance, foreign exchange, and insurance. An example was the facilitation of obtaining finance from the global capital market, including listing in overseas stock markets, debt issuing, project finance, and guarantee for overseas subsidiaries.

Despite the government's early effort to encourage non-state-owned firms to go overseas, the policy measures effectiveness was unclear. Some private Chinese firms felt that by 2006, government restrictions on their going overseas were largely gone, but they had not seen any helping hand yet. Government officials in the Ministry of Commerce felt that there were already many policy measures to assist the private firms (such as interest subsidies and deductibility of the cost of feasibility studies in the case of natural resource development), but the firms did not utilize them due to lack of information. According to some researchers in the government, while there were many

6. The Ministry of Commerce compiled a list of countries suitable for investment in textile and consumer electronics as early as January 2004. 
such promotional measures, their effectiveness was limited. It is interesting that the same researchers also questioned the rationale for subsidizing outward FDI with taxpayers' money.

Other private firms felt that they were not free to make quick investment decisions in a rapidly changing world economy. They complained that the investment facilitating measures were unclear and the approval of overseas investment project proposals still took a long time. Instead of going through successive levels of the Ministry of Commerce, then to the Commission on Development and Reform, and finally to the State Administration of Foreign Exchange, Chinese private firms wanted to have a one-stop shop to get all the required approvals. Some other private firms complained that, on the one hand, they were unable to obtain long-term loans from policy banks due to quotas on total lending and, on the other hand, commercial banks were not willing to take any risk in longer-term lending. Obtaining finance overseas with domestic collateral was not permitted by the Chinese government, but some private firms did it illegally anyway.

In 2006, China started to explore the idea of setting up "overseas China economic and trade cooperation zones" in host countries. These zones were perceived to serve several purposes: (a) to expand exports through the host economies that satisfy rules of origin in order to lessen bilateral trade frictions caused by rapid increase in Chinese exports; (b) to develop Chinese firms and to build Chinese brands in the global market place; (c) to reduce the country's bursting foreign reserves, and (d) to provide employment in host countries, thus contributing to the host economies and bilateral relations.

The reason for encouraging Chinese firms to invest in these zones rather than in other locations in the host countries is that Chinese firms would be more effective when they go overseas in groups, rather than as individual firms. That way, they will be able to support each other and to enjoy better support by host governments. In addition, the terms of agreement reached between host governments and Chinese investing firms will be firmed up as part of the bilateral investment agreements between the Chinese and host governments.

The hosts for these zones are chosen mostly on the basis of good bilateral relations, political stability, and comparative advantages. The host countries include North Korea, Russia, Kazakstan, Nigeria, and Pakistan. China envisions building fifty or so zones in the near future. By the end of November 2007, eight zones were approved, and one was officially established. Each approved zone may get RMB200 to 300 million of fiscal support and up to RMB2 billion of medium- to long-term loans. The following are examples of such zones: ${ }^{7}$

7. The information is taken from an article posted at http://mnc.people.com.cn/GB/ 54824/5127355.html. 
1. Haier-Ruba Economic and Trade Cooperation Zone in Pakistan: Officially established in November 2006, this is an industrial park mainly for the production of consumer electronics;

2. Ussuriysk Economic and Trade Cooperation Zone in Russia: Officially approved in October 2006, it focuses mainly on lumber, textiles, and logistics.

3. Lake Tai International Economic Cooperation Zone in Cambodia: It is mainly a regional trade center for distribution of goods produced in China's Jiangsu Province.

4. China Nonferrous Metal Group to invest in nonferrous mines in Zambia, especially in the Chambishi copper mine.

5. Transbaikai Economic and Trade Cooperation Zone in the area of Transbaikai, Chita, on the China-Russia border: It is mainly for industrial processing and cross-border trade.

\subsection{Patterns of China's Recent Outward FDI}

From this point onward, we shall omit the adjective "outward" if the meaning of FDI is clear without it. In this section, we first present China's aggregate annual FDI flow from 1982 to 2006 and its global shares in aggregate flows and stocks from 2002 to 2006. After that, we shall examine the sector composition and geographical distribution of China's FDI flows and stocks, to be followed by an analysis of the organizational background of the Chinese investors. Note that the difference between the FDI stocks (measured as of end of year) of two successive years is not necessarily equal to the FDI flow of the later year, as one might expect, due to reasons such as revaluations of the stock of investment.

\subsubsection{Amounts and Global Shares}

By the end of 2006, more than 5,000 Chinese firms had established nearly 10,000 overseas subsidiaries, joint ventures, and representative offices in 172 countries (regions) around the world. ${ }^{8}$ The flow of China's FDI from 1990 to 2006 is depicted in figure 14.1, where the data from 1982 to 2001 were based on UNCTAD's World Investment Reports, while data from 2002 were provided by MOFCOM based on international definitions and data collection methods. Note that statistics for FDI in financial industries in 2002 to 2005 was not available. To maintain consistency, the total FDI for 2006 shown in the figure excluded FDI in financial industries, whose statistics became available for the first time in that year.

In 2006, China's total FDI flow amounted to US\$21.16 billion, 24.4 percent of which was made up of new equity investment, and 31.4 percent of

8. In terms of the number of FIEs, by the end of 2006, 95 percent of them were subsidiaries and representative offices, while joint ventures accounted for only 5 percent. 


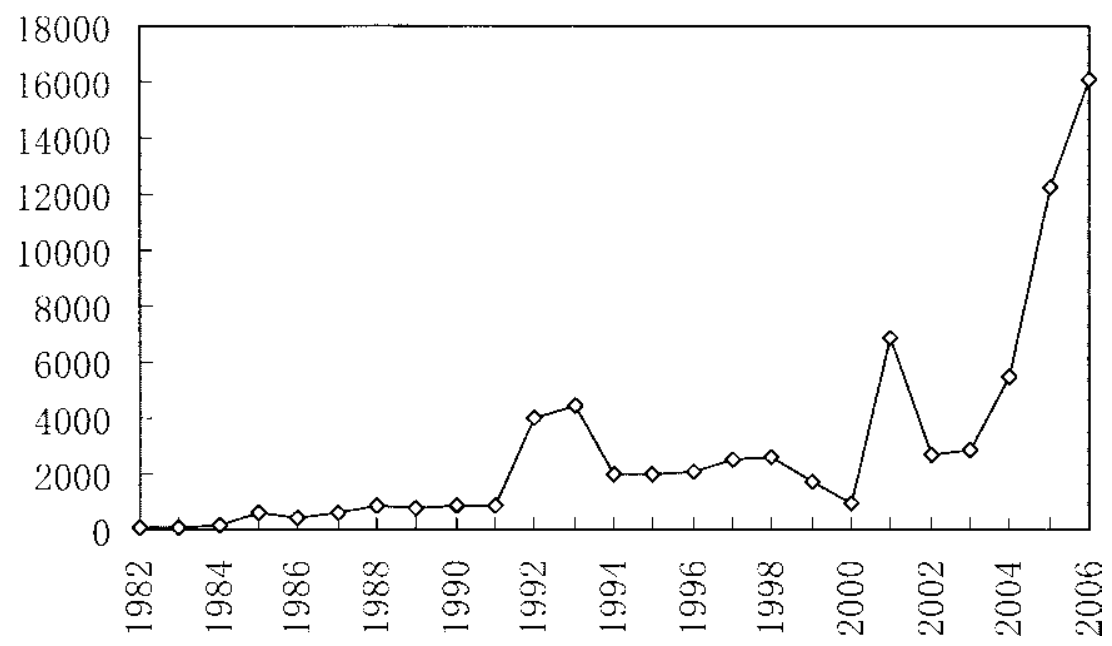

Fig. 14.1 China's outward FDI flow: 1982-2006 (US\$ millions)

Source: Ministry of Commerce, China (2006, 2007). Data for 1982-2001 are based on various issues of UNCTAD's World Investment Report, whereas data for 2002-2006 were compiled by the ministry.

which was made up of reinvestment of current profits. From a different angle, 39 percent of the total FDI took the form of merger of acquisition (M\&A), and 35.4 percent of FDI in financial industries took the form of M\&A. In addition, about half of the nonfinance FDI was in the form of loans extended by parent companies in China to its overseas units.

In 2002 to 2005, statistics for FDI in financial industries such as banking and insurance was not included due to lack of data, so the total amounts of shown in the figure were underestimates of China's actual FDI. In 2006, when statistics on FDI in financial industries became available for the first time, such FDI accounted for about one-sixth of the flow in that year and the stock at the end of the same year. ${ }^{9}$ If the shares of financial industries in China's total FDI flow and stock in 2006 were indicative of their importance in earlier years, then the statistics from 2002 to 2005 should be adjusted upward by about 17 percent.

China's FDI flow in nonfinance industries, on average, grew by 59.5 percent per annum (compound) between 2002 and 2006; its FDI stocks in the nonfinance industries, on average, grew by 34.5 percent per annum

9. By the end of 2006, Chinese state-owned commercial banks established a total of fortyseven branches, thirty-one subsidiaries, and twelve representative offices in twenty-nine countries and regions, including the United States, Japan, and the United Kingdom. The banking industry accounted for the lion's share of that year's FDI in the financial industries: 71 percent of flow and 79 percent of stock; insurance, second in place, accounted for 5 percent of the stock. 
China's outward foreign direct investment (FDI) flows and stocks in relation to the world's total FDI flows and stocks

\begin{tabular}{|c|c|c|c|c|c|}
\hline & 2002 & 2003 & 2004 & 2005 & 2006 \\
\hline $\begin{array}{l}\text { China's outward FDI flow } \\
\text { (U.S.\$ billions) }\end{array}$ & 2.7 & 2.85 & 5.5 & 12.26 & 21.16 \\
\hline $\begin{array}{l}\text { World's total FDI flow } \\
\text { (U.S. } \$ \text { billions) } \\
\text { Global share (\%) }\end{array}$ & $\begin{array}{c}540.7 \\
0.50\end{array}$ & $\begin{array}{c}560.1 \\
0.51\end{array}$ & $\begin{array}{c}877.3 \\
0.63\end{array}$ & $\begin{array}{c}837.2 \\
1.46\end{array}$ & $\begin{array}{c}1215.8 \\
1.74\end{array}$ \\
\hline $\begin{array}{l}\text { China's outward FDI stock } \\
\text { (U.S.\$ billions) }\end{array}$ & 22.9 & 33.2 & 44.8 & 57.2 & 90.63 \\
\hline $\begin{array}{l}\text { World's total FDI stock } \\
\text { (U.S.\$ billions) }\end{array}$ & $7,433.9$ & $\begin{array}{c}8,779.5 \\
0.38\end{array}$ & $\begin{array}{c}10,151.8 \\
0.44\end{array}$ & $\begin{array}{c}10,578.8 \\
0,54\end{array}$ & $\begin{array}{c}12,474.3 \\
0.73\end{array}$ \\
\hline
\end{tabular}

Notes: Stocks were measured at the end of each calendar year. The FDI flow and stock figures for 2003-2005 were underestimates of China's actual outward FDI flows and stocks because before 2006, FDI in financial industries were not included. In 2006, when data became available, FDI in financial industries accounted for about one-sixth of China's total FDI flow and stock in 2006. The global shares of China's FDI flows and stocks reported in this table are slightly different from those reported in the Ministry of Commerce's Statistical Bulletins, where the shares were calculated as percentages of China's flows and stock in the world's total FDI flows and stocks of the preceding (instead of the same) years.

(compound). Despite such rapid growth, its shares of the world's total FDI remained very small. As shown in table 14.1, China's FDI flow in 2006 accounted for about 1.74 percent of the world's total FDI flow and 0.73 percent of the world's total FDI stock. The figures in the earlier years were even smaller, and any adjustment to account for FDI in financial industries would not have made any significant difference.

When compared against the 2006 FDI statistics of other countries, the amounts of China's FDI flow and stock in 2006 would rank number seventeen and number twenty-four, respectively. Not only the world's major industrial economies such as the United States, the United Kingdom, and France, but also some of the small developed economies and major developing economies had more FDI than China. As examples of the latter, China's FDI flow in 2006 (US\$21.16 billion) was below that of Hong Kong (US $\$ 43.5$ billion), Sweden (US\$24.6 billion), and Holland (US\$22.7 billion) in the same year. Its FDI stock in 2006 (US\$90.63 billion) was below that of Holland, Australia, Ireland, Denmark, Hong Kong, Singapore, and Russia.

Nevertheless, given the expectation that China's FDI flows in the future will continue to grow rapidly relative to other source economies, it would be reasonable to expect China's rankings to continue to move up further.

\subsubsection{Sector Composition}

China's FDI flows and stocks in 2003 to 2006 by sector are shown in table 14.2. In 2006, 53.8 percent of China's FDI flow went into the services 


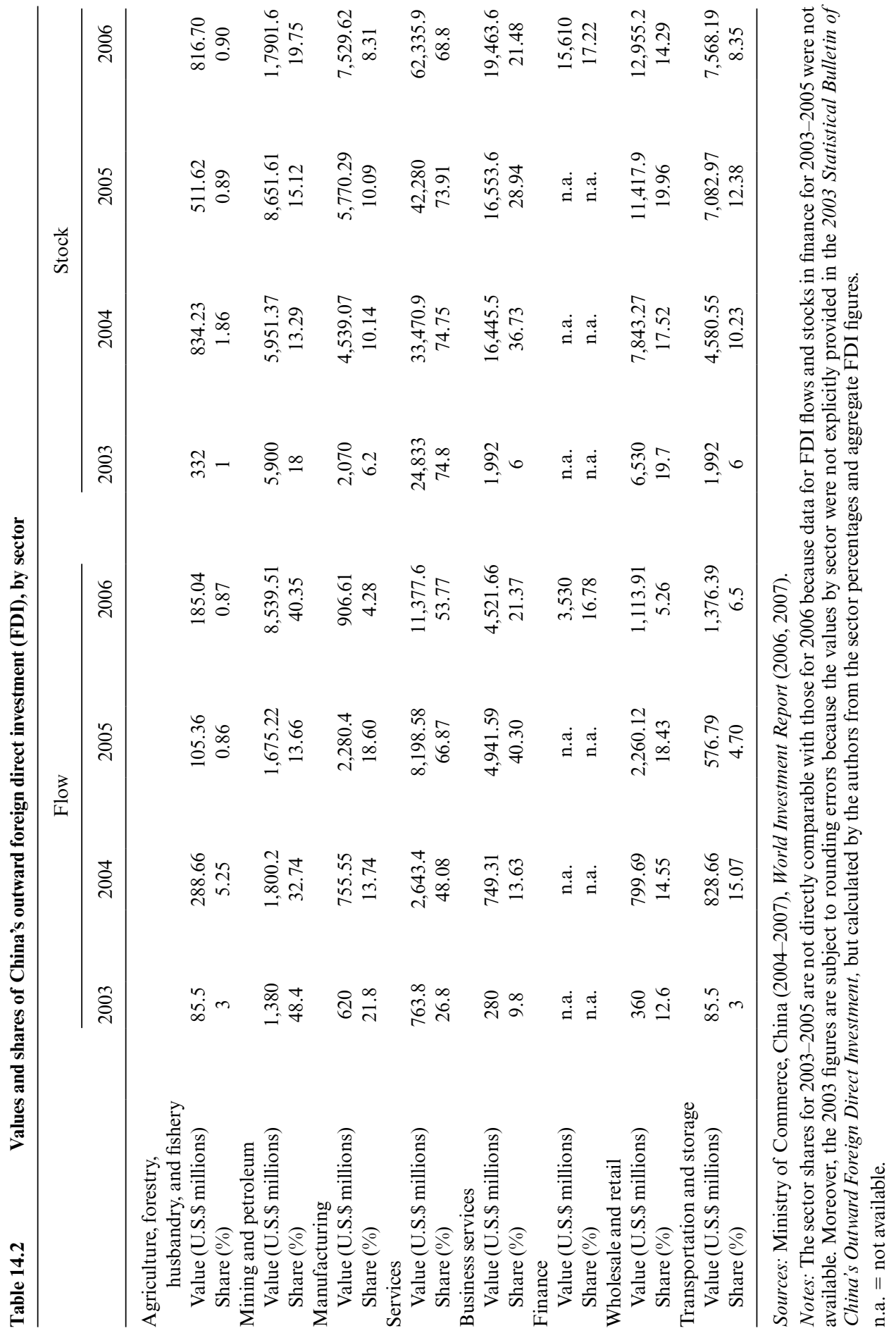


industries; 40.4 percent went into mining and petroleum; and a miniscule 4.3 percent went into manufacturing. ${ }^{10}$ Within the services sector, 21.4 percent went into business services, 16.8 percent into finance, 6.5 percent into transportation and storage (mainly marine transportation), and 5.3 percent into wholesale and retail (mainly imports and exports).

By the end of 2006, business services accounted for the largest share of China's outward FDI stock (21.5 percent), to be followed by mining and petroleum (19.8 percent), finance (17.2 percent), wholesale and retail (14.3 percent), transportation and storage ( 8.4 percent), and manufacturing ( 8.3 percent).

Due to the inclusion of finance for the first time in 2006, the shares of most of the other industries in 2006 inevitably fell from their 2005 levels. It is interesting to note that the total shares of the services sector in total FDI stock varied from the over 70 percent in 2003 to 2005 to close to 69 percent in 2006, signifying the predominant importance of the sector in China's FDI.

\subsubsection{Geographical Distribution}

In 2006, China's FDI flowed into 172 countries and regions spread over all continents except the Antarctica. Tables 14.3 and 14.4 show the geographical distributions of China's nonfinance FDI flows and stocks, respectively. In 2006, 48.0 percent of China's FDI flow was destined for Latin America, which exceeded the share of Asia, a new development that began in 2005. The bulk of China's investment in Latin America was made in two tax havens there: Cayman Islands and British Virgin Islands; the other well-known tax haven, the Bahamas, played a much smaller role. Investment in these and other tax havens typically results in reinvestment in other host economies, including China itself.

Until 2004, Asian economies accounted for more than half of China's investment flows. However, the share of Asia declined to 35.7 percent and 43.5 percent in 2005 and 2006, respectively, as investment shifted to Latin America. Despite this recent slow down, however, Asia still accounted for 64 percent of the total stock of China's FDI by the end of 2006, with 88 percent of it going to Hong Kong. Clearly, China's substantial FDI flows to Latin America were a relatively recent phenomenon.

The other regions in the world were not important destinations for China's FDI at all. In every year from 2003 to 2006, together they accounted for less than 10 percent of China's total flows and total stocks. Africa was slightly ahead of Europe in some years, but Europe was ahead of Africa in other years, and both accounted for more Chinese FDI than North America, whereas Oceania came in last. By the end of 2006, the shares of Africa,

10. This is mainly telecom equipment, computers and other electronic equipment, textile, electro-mechanical manufacture, transportation equipment, lumber processing, nonferrous metal, and so on. 
Table 14.3 Values and shares of China's nonfinance foreign direct investment (FDI) flows, by region

\begin{tabular}{|c|c|c|c|c|}
\hline & 2003 & 2004 & 2005 & 2006 \\
\hline \multicolumn{5}{|c|}{ Values of China's outward FDI flows (U.S.\$ millions) } \\
\hline Asia & $1,498.95$ & $3,000.27$ & $4,374.64$ & $7,663.25$ \\
\hline Africa & 74.79 & 317.42 & 391.68 & 519.86 \\
\hline Europe & 151.14 & 170.92 & 505.02 & 597.71 \\
\hline Latin America & $1,038.15$ & $1,762.72$ & $6,466.16$ & $8,468.74$ \\
\hline North America & 57.74 & 126.49 & 320.84 & 258.05 \\
\hline Oceania & 33.88 & 120.15 & 202.83 & 126.36 \\
\hline \multicolumn{5}{|c|}{ Share of China's outward FDI flows (\%) } \\
\hline Asia & 52.51 & 54.57 & 35.68 & 43.46 \\
\hline Africa & 2.62 & 5.77 & 3.19 & 2.95 \\
\hline Europe & 5.29 & 3.11 & 4.12 & 3.39 \\
\hline Latin America & 36.37 & 32.06 & 52.74 & 48.03 \\
\hline North America & 2.02 & 2.30 & 2.62 & 1.46 \\
\hline Oceania & 1.19 & 2.19 & 1.65 & 0.72 \\
\hline \multicolumn{5}{|c|}{ Relative ratio of China's outward FDI flows } \\
\hline Asia & 2.37 & 2.25 & 1.56 & 2.12 \\
\hline Africa & 0.79 & 2.38 & 1.02 & 1.08 \\
\hline Europe & 0.10 & 0.09 & 0.07 & 0.07 \\
\hline Latin America & 4.59 & 2.52 & 6.60 & 7.49 \\
\hline North America & 0.18 & 0.11 & 0.20 & 0.08 \\
\hline Oceania & 0.62 & 0.41 & -0.47 & 0.29 \\
\hline
\end{tabular}

Sources: China's data from Ministry of Commerce, China (2004-2007); world's data from UNCTAD's FDI database.

Notes: Share of China's outward FDI flow to region = China's outward FDI flow to region/ China's aggregate outward FDI flow. Relative ratio of China's outward FDI flow = share of China's outward FDI flow to region/share of world's FDI flow to region. The world's outward FDI to Oceania in 2005 was negative.

Europe, North America, and Oceania in China's total nonfinance FDI stock were 3.4 percent, 3.0 percent, 2.1 percent, and 1.3 percent, respectively.

When compared with the shares of the world's aggregate FDI flows to different regions, tables 14.3 and 14.4 show that the shares of China's FDI flows to Asia and Latin America were significantly higher than those of the world's, and its shares to Europe, North America, and Oceania were very low. In contrast, its share to Africa was more or less average, so the recent Chinese initiative to expand its economic role on the dark continent has yet to appear to the latter's future FDI figures.

The top ten recipients of China's FDI stock by the end of 2006 in descending order were Hong Kong, Cayman Islands, British Virgin Islands, the United States, South Korea, Russia, Australia, Macau, Sudan, and Germany. Immediately after them were Singapore, Mongolia, Kazakstan, Saudi Arabia, Zambia, Vietnam, Algeria, Thailand, Indonesia, and Japan. In 
Values and shares of China's outward nonfinance foreign direct investment (FDI) stocks, by region

\begin{tabular}{|c|c|c|c|c|}
\hline & 2003 & 2004 & 2005 & 2006 \\
\hline \multicolumn{5}{|c|}{ Values of China's outward FDI stocks (U.S.\$ millions) } \\
\hline Asia & $26,559.39$ & $33,409.53$ & $40,629.04$ & $47,978.04$ \\
\hline Africa & 491.22 & 899.55 & $1,595.25$ & $2,556.82$ \\
\hline Europe & 531.52 & 746.66 & $1,598.19$ & $2,269.82$ \\
\hline Latin America & $4,619.34$ & $8,268.37$ & $11,469.62$ & $19,694.37$ \\
\hline North America & 548.49 & 909.21 & $1,263.24$ & $1,587.02$ \\
\hline Oceania & 472.26 & 543.94 & 650.28 & 939.48 \\
\hline \multicolumn{5}{|c|}{ Share of China's outward FDI stocks (\%) } \\
\hline Asia & 79.94 & 74.61 & 71.02 & 63.95 \\
\hline Africa & 1.48 & 2.01 & 2.79 & 3.41 \\
\hline Europe & 1.60 & 1.67 & 2.79 & 3.03 \\
\hline Latin America & 13.90 & 18.47 & 20.05 & 26.25 \\
\hline North America & 1.65 & 2.03 & 2.21 & 2.12 \\
\hline Oceania & 1.42 & 1.21 & 1.14 & 1.25 \\
\hline \multicolumn{5}{|c|}{ Relative ratios of China's outward FDI stocks } \\
\hline Asia & 5.16 & 4.91 & 4.28 & 3.69 \\
\hline Africa & 0.60 & 0.80 & 1.03 & 1.30 \\
\hline Europe & 0.03 & 0.03 & 0.06 & 0.06 \\
\hline Latin America & 1.83 & 2.47 & 2.47 & 3.47 \\
\hline North America & 0.08 & 0.10 & 0.11 & 0.11 \\
\hline Oceania & 0.47 & 0.37 & 0.44 & 0.48 \\
\hline
\end{tabular}

Sources: China's data from Ministry of Commerce, China (2006); world's data from UNCTAD's FDI database.

Notes: Share of China's outward FDI stock to region = China's outward FDI stock to region/ China's aggregate outward FDI stock. Relative ratio of China's outward FDI to region = share of China's outward FDI stock to region/share of world's FDI stock to region.

terms of FDI flows in 2006, the top ten recipients in descending order were Cayman Islands, Hong Kong, British Virgin Islands, Russia, the United States, Singapore, Saudi Arabia, Algeria, and Zambia. Immediately after them were Mongolia, Germany, Nigeria, Iran, Indonesia, Sudan, Vietnam, Kazakstan, South Africa, and Japan.

Both lists were indicative of the role of natural resources in attracting Chinese FDI to Africa, central Asia, Southeast Asia, and Australia.

Given that 86.8 percent of China's total FDI flows in 2006 was made in three tax havens (namely, Hong Kong, Cayman Islands, and British Virgin Islands), and at least 80 percent and 78 percent of its FDI flow in 2005 and 2004 were made in them, respectively, the true breakdown of the destination of China's FDI was largely unknown. Our attempts to obtain information about China's actual investment destinations from news databases and the annual reports of publicly listed Chinese companies, unfortunately, proved to be unsuccessful. 


\subsubsection{Identity of Chinese Investors}

The bulk of China's FDI was made by the country's state-owned enterprises (SOEs), in particular, those large multinational companies that were administered by the Central Government's ministries and agencies. The shares of FDI flows in 2003 to 2006 made by SOEs under the Central Government were 73.5 percent, 82.3 percent, 83.2 percent, and 86.4 percent, respectively. Their shares of FDI stocks by the end of 2004 to 2006 were 85.5 percent, 83.5 percent, and 82.1 percent, respectively. The remaining shares of FDI flows and stocks were made by SOEs administered by regional governments and non-SOEs that are owned collectively and privately. ${ }^{11}$ The private firms' share of FDI was miniscule; in 2004, private firms in China accounted for 1.5 percent of the country's total FDI flow, and by the end of 2006 their share of China's total FDI stock was 1 percent.

At the end of 2004, the thirty Chinese multinational companies with the largest stocks of FDI accounted for 80.4 percent of China's total nonfinance FDI stock. Over twenty of them were SOEs administered by the Central Government. The remainder included the listed companies Lenovo, TCL, Beida Jade Bird, ${ }^{12}$ and other listed companies that are owned by the regional governments of Beijing, Shanghai, and Guangdong. ${ }^{13}$

\subsection{China's FDI in the Energy Sector}

Despite frequent news reports on China's FDI in the energy sector, no systematic data are available in the public domain. As pointed out in the preceding, China's go overseas policy covers not only outward FDI, but also the undertaking of overseas construction and engineering projects as well as the export of labor services. China's energy policy as stated in the 11th Five-Year plan (2006-2010) was to develop domestic supply as the primary means of meeting domestic demand, and to supplement that supply by tapping foreign sources of energy. To secure the foreign supply of oil, gas, and other forms of energy, China has relied on both long-term contracts and FDI. In some cases, these contracts may go beyond the purchase and sale of oil and gas. For example, in an agreement reached in 2004, China swapped its construction projects for Brazil's oil. ${ }^{14}$

11. In China, the provincial-level regions include provinces, provincial-level autonomous regions, and provincial-level municipalities directly administered under the central government.

12. In the 2006 list, Huawei and Haier replaced TCL and Beijing Jade Bird on the top thirty list.

13. For example, GDH Limited and Shum Yip Holdings Company Limited are from Guangdong, whereas Shanghai Automotive Industry Corporation and Shanghai Baosteel Group Corporation are from Shanghai.

14. This agreement was reached in May 2004 when Brazil's president Lula visited China. Under the agreement, China was to invest US\$1 billion in a port facilities in return for Brazil's iron ore, oil, bauxite, and other raw materials of equal total value. 
China's three biggest oil companies in descending order are China National Petroleum Corporation (CNPC), China Chemical and Petroleum Corporation (Sinopec), and China National Offshore Oil Corporation (CNOOC) ${ }^{15}$ In terms of the importance of overseas operations, the order is CNPC, CNOOC, and Sinopec.

China National Petroleum Corporation started its overseas ventures in 1995. A decade later, it had four production bases in North Africa (mainly Sudan); Central Asia (mainly Kazakstan); South America (mainly Venezuela); and Asia and Australia, with annual target production of 35 million tons. In 2006 it had sixty-five cooperative projects in twenty-five countries, producing 54 million tons of oil (of which 28 million tons went to the company) and 5.7 billion cubic meters of natural gas (of which 3.5 billion cubic meters went to the company).

In 2002, CNOOC acquired three oil/gas fields in Australia and Indonesia at the cost of US\$1.2 billion, including offshore oil fields in Indonesia that were acquired from Spain's Repsol-YPE; the latter oil fields yielded 5.4 million tons of oil for the company. In 2006, it expanded its operations in Africa by acquiring a Nigerian tract at a cost of US $\$ 2.068$ billion and signed an agreement with Kenya for the largest area ever obtained from its overseas agreements. In that year, it also reached an agreement with Vietnam to jointly develop oil in the South China Sea, received permission to participate in the second largest gas field in Iran, and acquired a 25 percent stake in four offshore exploration tracts in Australia.

Sinopec established its international subsidiary Sinopec International Petroleum Exploration and Production (SIPC) in 2001 for the purpose of going overseas. By 2005, it had oil and gas projects in Iran, Saudi Arabia, Libya, Angola, Congo, Gabon, Kazakstan, Yemen, and Ecuador. In that year, it signed a joint venture agreement with the Russian oil company Rosneft to explore and develop oil and gas, the first of its kind involving a Russian oil company and China's three major oil companies. It also had activities in Australia and Indonesia. In 2006, it signed an agreement with Rosneft on a framework of strategic cooperation and joined forces with India's Oil and Natural Gas Corporation (ONGC) to acquire a Columbian oil company.

An interview with some businessmen in Beijing has revealed that they were not aware of any government policies explicitly implemented to support Chinese firms in the energy sector to go overseas, but they could see three advantages the energy firms enjoy with regard to outward FDI. First, they have cooperated with foreign partners for a long time, so they are much more familiar with foreign countries than nonenergy firms. Second, they are SOEs (state-owned enterprises), so they enjoy preferential policies that are specific to SOEs. Third, the energy firms they buy are good collateral

15. The ratios of their market capitalization in 2007 were about 5:2:1. 
for loans, so banks are willing to finance their M\&A activities overseas. Separately, Sinosure (China Export and Credit Insurance Corporation) has provided insurance to Chinese oil companies big and small in the areas of equity investment, debt financing, and working capital loans.

To support Chinese oil companies going overseas, the Chinese government has considered setting up a foreign exchange fund to facilitate the acquisition of and merger with foreign oil companies. However, whether this should be done remains controversial.

\subsection{Determinants of China's Outward FDI Flows and Stocks: A Gravity Model Analysis}

The China Ministry of Commerce (2007) has released data on the FDI flows and stocks by destination in 2003 to 2006 . There were 151 host economies in the sample for FDI flows and 172 host economies in the sample for FDI stocks. However, due to lack of macroeconomic data for many of these economies for some years, we are forced to use two substantially smaller subsamples, namely, a subsample of 90 to 98 host economies for flows and a subsample of 125 to 150 host economies for stocks, depending on the choice of our explanatory variables and their data availability. The gravity equation to be estimated for the purpose of uncovering the determinants of China's outward FDI is as follows: ${ }^{16}$

$$
\begin{aligned}
\log \left(\mathrm{FDI}_{i, t}\right)= & \alpha+\beta_{1} \cdot \log \left(\mathrm{GDP}_{i, t}\right)+\beta_{2} \cdot \log \left(\mathrm{PGDP}_{i, t}\right)+\beta_{3} \cdot \log \left(\text { dist }_{i}\right) \\
& +\beta_{4} \bullet \text { ChineseLang }_{i}+\beta_{5} \bullet \text { Border }_{i}+\beta_{6} \cdot \text { Landlock }_{i} \\
& +\beta_{7} \cdot \text { Island }_{i}+\beta_{8} \bullet \text { Dummy }_{t},
\end{aligned}
$$

where $\mathrm{FDI}_{i t}$ stands for China's FDI flow to (or FDI stock in) economy $i$ in year $t, \mathrm{GDP}_{i t}$ and $\mathrm{PGDP}_{i t}$ stand for the host economy's real GDP and real per capita GDP, respectively ${ }^{17}{ }^{\text {dist }}{ }_{i}$ stands for the distance between the economy's capital and Beijing, ChineseLang ${ }_{i}$ is a dummy variable for the use of the Chinese language, Border ${ }_{i}$ stands for its sharing a common border

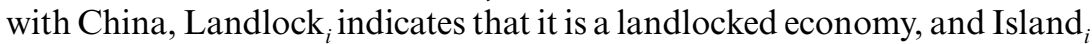
indicates that it is an island economy.

Because FDI that goes into tax havens and offshore financial centers will typically be invested elsewhere, these host economies are not the ultimate destination of the FDI. In order to avoid the influence of FDI that went to tax havens and offshore financial centers, we carried out the estimation

16. In theory, China's exports to its host economies could be a factor in its outward FDI to them. However, the coefficient of correlation between them was rather small. The coefficient of correlation between China's annual exports and FDI flow in 2003 to 2006 ranged from 0.3 to 0.5 ; that between China's annual exports and year end FDI stock ranged from 0.53 to 0.55 during the same period. Due to these results, we have decided not to include China's exports as an explanatory variable in the regression equation.

17. The estimation results are qualitatively similar whether the GDP of host economies was measured in nominal or real terms. 
Table 14.5

Regression results for recipient economies of China's outward foreign direct investment (FDI) flows (2003-2006)

\begin{tabular}{lccc}
\hline & Full sample & $\begin{array}{c}\text { Tax haven economies } \\
\text { (OECD list) excluded }\end{array}$ & $\begin{array}{c}\text { Offshore financial } \\
\text { center economies } \\
\text { (IMF list) excluded }\end{array}$ \\
\hline $\log (\mathrm{GDP})$ & $0.34782^{* * *}$ & $0.37272^{* * *}$ & $0.35160^{* * *}$ \\
$\log (\mathrm{PGDP})$ & $(0.06634)$ & $(0.07164)$ & $(0.07252)$ \\
& -0.07953 & -0.09717 & -0.07004 \\
$\log ($ dist $)$ & $(0.10504)$ & $(0.10908)$ & $(0.11214)$ \\
ChineseLang & -0.33384 & $-0.43786^{* *}$ & $-0.45020^{* *}$ \\
& $(0.21989)$ & $(0.21883)$ & $(0.21889)$ \\
Border & $4.21955^{* * *}$ & $4.26286^{* * *}$ & \\
Landlock & $(0.77379)$ & $(0.76620)$ & $0.83061^{* *}$ \\
Island & $1.12032^{* * *}$ & $0.98454^{* *}$ & $(0.39380)$ \\
& $(0.39081)$ & $(0.38849)$ & $-0.53456^{*}$ \\
$R^{2}$ & $-0.59648^{* *}$ & $-0.57681^{* *}$ & $(0.27474)$ \\
No. of observations & $(0.27200)$ & $(0.26986)$ & -0.37500 \\
& -0.19364 & -0.35730 & $(0.35283)$ \\
\hline
\end{tabular}

Notes: Standard deviations are in parentheses. OECD = Organization for Economic Cooperation and Development.

${ }^{a}$ Because Hong Kong, Macau, and Singapore appeared on the International Monetary Fund (IMF) list, and Taiwan had no FDI from China, the ChineseLang dummy became irrelevant for the sample that excluded offshore financial center economies.

$* * *$ Significant at the 1 percent level.

**Significant at the 5 percent level.

*Significant at the 10 percent level.

of the gravity equation first by using the full sample and then by excluding them. Because there are many country lists of tax havens and offshore financial centers, we adopt the two most widely used lists, namely, the tax haven list issued by the OECD in 2000, ${ }^{18}$ and the offshore financial center list issued by the IMF in $2006 .{ }^{19}$

The estimation results of the gravity equation (except those for the time dummies) for FDI flows are reported in table 14.5, and those for FDI stocks are reported in table 14.6. It should be pointed out that the real GDP data for the entire period were taken from IMF's World Economy Outlook, and

18. The OECD report listed thirty-five countries/regions as tax havens: Andorra, Anguilla, Antigua and Barbuda, Aruba, Bahamas, Bahrain, Barbados, Belize, British Virgin Islands, Cook Islands, Dominica, Gibraltar, Grenada, Guernsey/Sark/Alderney, Isle of Man, Jersey, Liberia, Liechtenstein, Maldives, Marshall Islands, Monaco, Montserrat, Nauru, The Netherlands Antilles, Niue, Panama, Samoa, Seychelles, St Lucia, St. Christopher and Nevis, St. Vincent and the Grenadines, Tonga, Turks and Caicos, U.S. Virgin Islands, and Vanuatu.

19. The IMF report listed forty-six countries/regions as offshore financial centers: Bahrain, Andorra, Aruba, Hong Kong Special Administrative Region (SAR), Belize, Anguilla, 
Table 14.6 Regression results for recipient economies of China's outward foreign direct investment (FDI) stocks (2003-2006)

\begin{tabular}{lccc}
\hline & Full sample & $\begin{array}{c}\text { Tax haven countries } \\
\text { (OECD list) excluded }\end{array}$ & $\begin{array}{c}\text { Offshore financial } \\
\text { center countries } \\
\text { (IMF list) excluded }\end{array}$ \\
\hline $\log ($ GDP $)$ & $0.62499^{* * * *}$ & $0.70896^{* * *}$ & $0.67533^{* * * *}$ \\
$\log ($ PGDP) & $(0.05363)$ & $(0.06023)$ & $(0.05803)$ \\
& $-0.56010^{* * *}$ & $-0.64311^{* * *}$ & $-0.62610^{* * *}$ \\
$\log ($ dist $)$ & $(0.08950)$ & $(0.09454)$ & $(0.09419)$ \\
& 0.06776 & -0.09136 & -0.10108 \\
ChineseLang & $(0.20567)$ & $(0.20979)$ & $(0.20340)$ \\
& $4.39037^{* * *}$ & $4.61002^{* * *}$ & \\
Border & $(0.69751)$ & $(0.69994)$ & $0.74908^{* * *}$ \\
& $1.28780^{* * *}$ & $1.01828^{* * *}$ & $(0.36717)$ \\
Landlock & $(0.36532)$ & $(0.37049)$ & $-0.79178^{* * *}$ \\
Island & $-0.82442^{* * *}$ & $-0.76846^{* * *}$ & $(0.22735)$ \\
& $(0.22817)$ & $(0.22929)$ & 0.01671 \\
$R^{2}$ & 0.21579 & -0.18572 & $(0.29391)$ \\
No. of observations & $(0.25107)$ & $(0.27686)$ & 0.3087 \\
\hline
\end{tabular}

Note: See table 14.5 notes.

${ }^{a}$ Because Hong Kong, Macau, and Singapore appeared on the International Monetary Fund (IMF) list, and Taiwan had no FDI from China, the ChineseLang dummy became irrelevant for the sample that excluded offshore financial center economies.

*** Significant at the 1 percent level.

**Significant at the 5 percent level.

similar estimation results were obtained when the real GDP data for 2003 and 2004 were substituted with real GDP data from the Penn World Tables, which do not have data for 2005 and 2006.

The results in table 14.5 reveal that, as expected, the host economies' GDP had a positive impact, whereas their respective distances from China had a negative impact on attracting China's FDI.$^{20}$ The landlocked economies seemed to be at a disadvantage in attracting Chinese FDI, while sharing a common border with China (which included some landlocked economies) was a positive factor in attracting China's FDI. While the use of the Chinese language had a positive impact on China's FDI, there were only four such

Grenada, Ireland, Bermuda, Antigua and Barbuda, Lebanon, Luxembourg, Cayman Islands, Bahamas, Malaysia (Labuan), Malta, Cyprus, Barbados, Marshall Islands, Switzerland, Gibraltar, British Virgin Islands, Nauru, Guernsey, Cook Islands, Turks and Caicos Islands, Isle of Man, Costa Rica, Jersey, Dominica, Macao SAR, Liechtenstein, Mauritius, The Netherlands Antilles, Monaco, Niue, Montserrat, Palau, Samoa, Panama, Seychelles, St. Kitts and Nevis, Singapore, St. Lucia, St. Vincent and the Grenadines, and Vanuatu.

20. But the coefficient for the GDP variable was not statistically significant when the full sample was used, that is, when the influence of tax havens was not controlled for. 
economies in the world. ${ }^{21}$ As in other studies, the language variable served to capture the impact of common culture and custom, and in the case of Hong Kong and Macau, it probably also captured their political affiliation with China. The host economy's per capita GDP and its being an island had no impact at all.

The estimation results about China's FDI stocks as contained in table 14.6 are similar to those contained in table 14.5, with two exceptions: first, real per capita GDP had a significantly negative impact, suggesting that, in the past, China's FDI tended to be negatively correlated with the level of development of the host economies; second, the distance ceased to have any significant impact on China's FDI. To the extent that FDI flows are more volatile than stocks, one could argue on theoretical grounds that the gravity model has greater validity for stocks than for flows and, thus, has greater explanatory power. ${ }^{22}$ Hence, the negative relationship between China's FDI and the real per capita GDP of the host economies should not be ignored. Nevertheless, the determinants of China's FDI as revealed in tables 14.5 and 14.6 should be interpreted with caution because a predominant share of the FDI was invested in the world's tax havens, implying the investment's ultimate destination is to a large extent unknown.

\subsection{Determinants of the Outward FDI of the World's Source Economies: Benchmarks for China}

On the one hand, because there was a structural change in China's outward FDI in recent years (e.g., less restrictions due to increased supply of foreign reserves, more liberal approval processes, government encouragement, etc.), its past FDI flows from the 1980s would tend to underestimate China's future investment flows. On the other hand, the number of observations from 2003 to 2006 is too small to make any estimation reliable. An alternative approach is to use the experiences of the world's source economies at various stages of economic development over a reasonably long period of time to explore the determinants of China's outward FDI. Still another approach is to use the experiences of Japan and South Korea, two East Asian economies that are more advanced than China in their stages of economic development and their overseas investment, as benchmarks for China's past and future FDI.

A question is whether the experience with FDI far in the past is good for predicting investment behavior in the future because FDI has become increasingly more important in an increasingly globalized world economy.

21. Outside China, the Chinese language is used in Hong Kong, Macao, Singapore, and Taiwan. However, China's outward FDI in Taiwan was zero due to policy restrictions on the part of Taiwan's government.

22 . When the two regression equations use the same set of explanatory variables, the $R^{2}$ for stocks is indeed greater than that for flows. 
The experience of Japan, South Korea, and other leading investor countries in the world might fail to capture the dynamics of China's future FDI. Another question is whether the experience of the world's economies is relevant to China's FDI in view of the fact that the key Chinese investors are closely related to various levels of government.

We have no good answers to these two questions. We do not know if the key Chinese investors' relationships with their governments will lead them to make more or less FDI than if they were privately owned, and we believe that the world's experience with FDI may contain useful hints about China's future aggregate FDI. In any event, we believe that having some bases of benchmarking would seem better than having none at all.

\subsubsection{Determinants of FDI Flows for 211 Source Economies}

We use a sample of 211 source economies that had the relevant macroeconomic statistics during 1980 to 2005. More specifically, the equation for outward FDI is as the following:

$$
\begin{aligned}
\log \left(F_{i, t}\right)= & \beta_{1} \cdot \log \left(\mathrm{GDP}_{i, t}\right)+\beta_{2} \cdot \log \left(\mathrm{PGDP}_{i, t}\right)+\beta_{3} \cdot \log \left(\mathrm{FR}_{i, t}\right) \\
& +\beta_{4} \cdot \operatorname{Open}_{i, t}+\beta_{5} \bullet \operatorname{Dep}_{i, t}+\beta_{6} \bullet \mathrm{WTH}_{i, t}+\beta_{6} \bullet t+C,
\end{aligned}
$$

where $F_{i, t}$ is source economy i's outward FDI flow or stock at time $t, \mathrm{GDP}_{i, t}$ and PGDP $_{i, t}$ are the economy's real GDP (constant prices: chain series) and real per capita GDP, ${ }^{23} \mathrm{FR}_{i, t}$ stands for its foreign reserves, Open stands for its degree of openness (which is represented by "trade openness," TOpen $=$ total trade/GDP, ${ }^{24}$ or "financial openness," FOpen = inward FDI flow/ GDP $)^{25}, \operatorname{Dep}_{i, t}=\log \left(\operatorname{Exch}_{i, t}\right)-\log \left(\operatorname{Exch}_{i, t-1}\right)$ measures the rate of depreciation of country $i$ 's currency, or the difference between the current period log value of exchange rate (the number of local currency per U.S. dollar) and that of the previous period, $C$ is a constant, and $\mathrm{WTH}_{i}$ stands for a dummy variable associated with the status of tax heaven or offshore financial center but weighted by its relative importance in attracting FDI (i.e., its inward FDI divided by the world's total inward FDI). The variables $F_{i, t}, \mathrm{FR}_{i, t}$, exports, and imports are adjusted with the U.S. Consumer Price Index (CPI) index with 2000 as the base year. ${ }^{26}$

The estimation results are reported in table 14.7.27 They indicate that

23. Data on real GDP before 2004 are obtained from PWT6.2 and that after 2005 from the World Bank's World Development Indicators (WDI), while data on population are obtained from $W D I$.

24. The total trade-GDP ratio of an economy is given by the ratio of the nominal value of the sum of its exports and imports to its nominal GDP.

25. The inward FDI flow-GDP ratio of an economy is given the ratio of the nominal value of inward FDI flow to its nominal GDP.

26. Data on foreign reserves, exports, imports, and U.S. CPI are obtained from the World Bank's World Development Indicators and IMF's IFS statistics, and data on outward FDI flows are obtained from the UNCTAD's FDI database

27 . Here we only report the results when $T$ Open is used as explanatory variable. The results with $F$ Open as an explanatory variable are similar. 
Table 14.7

Regression results for source economies' outward foreign direct investment flows and stocks (1980-2005)

\begin{tabular}{lccccc}
\hline & \multicolumn{2}{c}{ Flows } & & \multicolumn{2}{c}{ Stocks } \\
\cline { 2 - 3 } \cline { 5 - 6 } & $(1)$ & $(2)$ & & $(3)$ & $(4)$ \\
\hline $\log (\mathrm{GDP})$ & $0.91625^{* * *}$ & $0.89516^{* * *}$ & & $0.99006^{* * *}$ & $0.95071^{* * *}$ \\
& $(0.05672)$ & $(0.05724)$ & & $(0.04342)$ & $(0.04340)$ \\
$\log (\mathrm{PGDP})$ & $1.18505^{* * *}$ & $1.22769^{* * *}$ & & $1.06723^{* * *}$ & $1.12771^{* * *}$ \\
& $(0.06636)$ & $(0.06713)$ & & $(0.04991)$ & $(0.049990)$ \\
$\log (\mathrm{FR})$ & $0.14962^{* * *}$ & $0.11780^{* *}$ & & 0.04900 & 0.01887 \\
& $(0.04955)$ & $(0.04977)$ & & $(0.03825)$ & $(0.03800)$ \\
$T$ Open & $0.56185^{* * *}$ & $0.25752^{*}$ & & $0.310^{* * *}$ & $-0.18991^{*}$ \\
& $(0.12659)$ & $(0.15622)$ & & $(0.097993)$ & $(0.11861)$ \\
Dep & $-0.70089^{* * *}$ & $-0.71483^{* * *}$ & & $-0.30845^{* * *}$ & $-0.31888^{* * *}$ \\
& $(0.12670)$ & $(0.12701)$ & & $(0.09844)$ & $(0.09763)$ \\
$t$ & $0.02066^{* * *}$ & $0.02217^{* * *}$ & & $0.05892^{* * *}$ & $0.06201^{* * *}$ \\
WTH (OECD) & $(0.00799)$ & $(0.00805)$ & & $(0.00593)$ & $(0.00590)$ \\
& $808.28124^{* * *}$ & & $488.99461^{* * *}$ & \\
WTH (IMF) & $(156.46368)$ & & & $(111.13303)$ & $103.64531^{* * *}$ \\
& & $67.63911^{* * *}$ & & & $(13.45273)$ \\
$R^{2}$ & & $(17.11093)$ & & & 0.6856 \\
No. of & & 0.6108 & & 0.6804 & 2,411 \\
observations & 2,088 & 2,088 & 2,411 & \\
\hline
\end{tabular}

Notes: Standard deviations are in parentheses. OECD = Organization for Economic Cooperation and Development; IMF = International Monetary Fund.

***Significant at the 1 percent level.

**Significant at the 5 percent level.

*Significant at the 10 percent level.

both real GDP and real per capita GDP had a significantly positive impact, whereas currency depreciation had a significantly negative impact on the source economies' outward FDI flows (equivalently, currency revaluation had a positive impact on outward FDI). The coefficients for the GDP variables were similar in magnitude regardless of whether the OECD list of tax havens or the IMF list of offshore financial centers was used. It is interesting that the coefficient of real GDP was slightly below unity, but that for per capita real GDP was slightly above unity, with the latter suggesting that the stage of economic development appeared to be an even more important determinant of FDI outflows than the size of the source economies.

As expected, the coefficient of foreign reserves was positive. However, it was statistically significant only for FDI flows. The coefficient of openness was significantly positive for FDI flows, but surprisingly, the coefficient for FDI stocks was negative at the 10 percent significance level when the IMF list of offshore financial centers was used. The coefficients of the tax haven dummy variable $\mathrm{WTH}_{i}$, while significantly positive, had substantially different sizes depending on the list of tax havens. 
After controlling for real GDP, real per capita GDP, foreign reserves, openness, currency depreciation, and tax haven status, there remained a significantly positive time trend for both FDI flow and stock, which supports the hypothesis that FDI becomes increasingly important over time for all economies.

In view of the pressure generated by China's bursting foreign reserves (US\$1.9 trillion by November 2008) on its money supply and its exchange rate, it had been China's official policy to encourage foreign reserves to leave the country until the onset of the global financial and economic crisis of 2008: "To open the flood gate," according to the official policy speak. As a result of this new policy, there will be a significant increase in both outward direct investment and portfolio investment. So far, there are two major channels of "flood letting": (a) overseas investment by qualified domestic institutional investors (QDII) to initially invest in Hong Kong but ultimately in the entire world; (b) overseas investment by a state-owned foreign investment arm called China Investment Corporation (CIC), whose initial investment fund was US\$200 billion..$^{28}$ China announced in August 2007 that individual Chinese citizens would be allowed to invest any amount overseas via Tianjin's Seashore New Zone and other cities. This policy, popularly dubbed "Hong Kong Stocks through Train" that was expected to be extended to investment in the rest of the world over time, was later aborted due to internal conflicts of interest and concerns about national financial security, such as uncontrolled capital flight and further weakening of a collapsed Chinese stock market.

With the onset of the biggest financial and economic crisis since the Great Depression in the 1930s and serious losses by CIC, however, Chinese firms started to reassess their foreign investment strategies. Whether this will have a permanent major negative impact on China's outward FDI remains to be seen.

\subsubsection{Determinants of Japan and South Korea's Aggregate FDI}

Japan and Korea are China's two significant East Asian neighbors that have gone through stages of economic development that China is expected to go through in the future. In terms of per capita real GDP, China's present development stage is similar to Japan's in the 1960s and Korea's in the 1980s..$^{29}$ Thus, Japan and South Korea's experiences with outward FDI could be indicative of the development of China's future FDI. In section 14.1, we noted that Hong and Sun (2004), by comparing growth trends, found that

28. Even before the investment company was officially established, China invested US\$3 billion in the Blackstone Group, a private equity firm, in May 2007. After the subprime debacle that hurt many major investment banks, the company invested US\$5 billion in Morgan Stanley for a 9.9 percent stake.

29. According to PWT6.2, in 2004 China's real per capita GDP (at Laspeyres constant prices) was US\$ 5,333, which was close to that of Japan in 1962 (US\$ 5,550) and of Korea in 1983 (US\$ 5,457). 


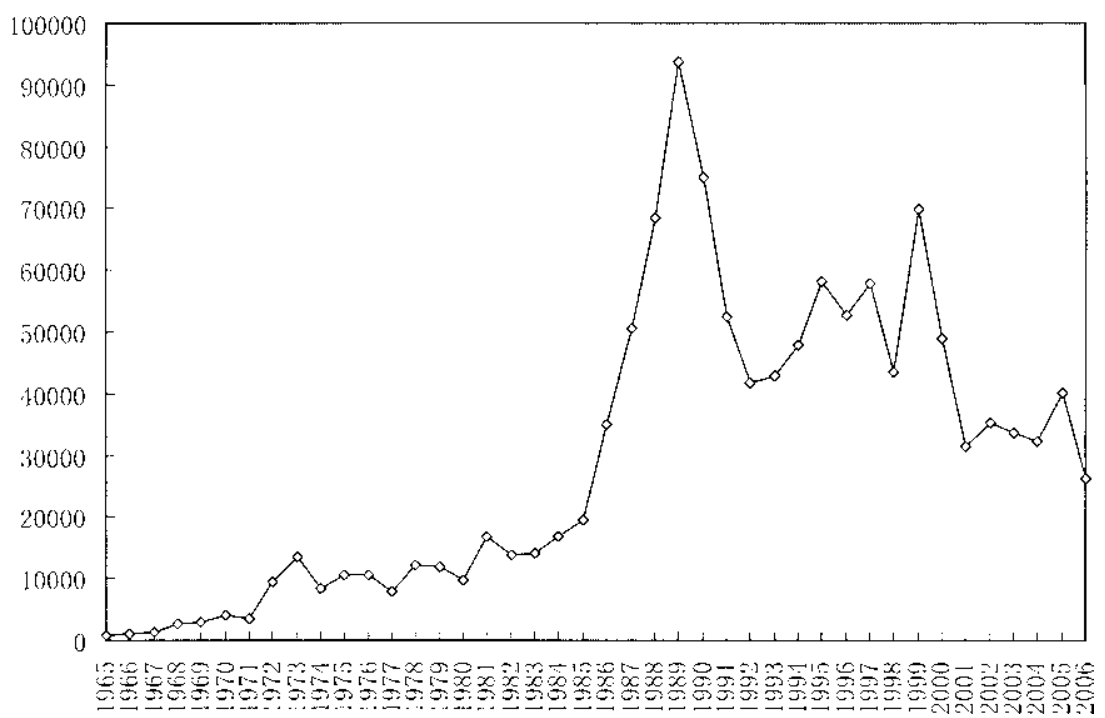

Fig. 14.2 Japan's outward FDI flow (US\$ millions at 2000 constant price), 1965-2006

Sources: Japan External Trade Organization (JETRO) and International Financial Statistics (IFS).

China's aggregate FDI outflows during 1988 to 2002 were quite similar to those of South Korea during the same period and to those of Japan in 1968 to 1982. Instead of directly comparing growth trends, in this section, we shall match China's stages of economic development as measured by per capita real GDP with those of South Korea and Japan.

Figures 14.2 and 14.3 depict, respectively, Japan's aggregate outward FDI flow from 1965 to 2006 and Korea's aggregate outward FDI flow from 1980 to 2006. From these figures, we observe that each country experienced two high growth periods of outward FDI flow. From 1967 to 1973, Japan's FDI flow increased by about 855 percent (which translated into a compound average rate of growth of 45.6 percent per annum), and from 1985 to 1989 its flow increased by about 380 percent (which translated into a compound average rate of growth of 48.0 percent per annum). Similarly, from 1989 to 1996 , Korea's outward FDI flow increased by about 517 percent (which translated into a compound average rate of growth of 29.7 percent per annum), and from 2003 to 2006, its flow increased by about 141 percent (which translated into a compound average rate of growth of 34.1 percent per annum). Interestingly, Japan's real per capita GDP (measured at Laspeyres constant prices) in 1968, 1973, and 1985 was US\$ 9,286; US\$ 13,359; and US\$ 17,434, respectively, and Korea's real per capita GDP (at Laspeyres constant prices) in 1989, 1996, and 2003 were US\$ 8,689; 


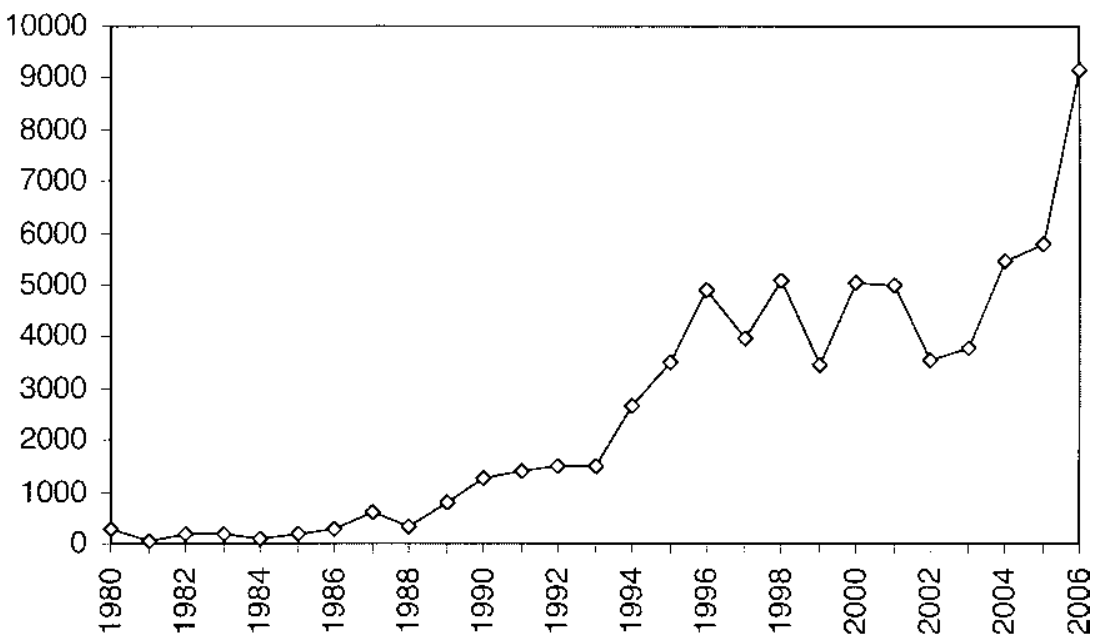

Fig. 14.3 Korea's outward FDI flow (US\$ millions at 2000 constant price), 1980-2006

Sources: Korea Eximbank and IFS; FDI figures were deflated by U.S. CPI.

Note: The figure for 1980 stands for the cumulated outward FDI flows up to 1980.

US\$ 14,115 ; and US $\$ 17,595$, respectively. For these two countries, US\$ 8,300 ; US\$ 14,200 ; and US\$ 17,000 appeared to be three watersheds of outward FDI.

A simplistic idea is that when China's real GDP reaches these critical levels, its FDI may grow at comparable rates. However, because China has greater income disparity, and that outward FDI tends to originate mostly from the more advanced Chinese regions, even if Japan and Korea's experiences were to be repeated in China, the watersheds may occur at lower levels of real per capita GDP. Moreover, as the extent of globalization in the twenty-first century is greater than that in the 1970s as well as the 1990s, China's FDI may exceed those of Japan and South Korea for the same level of real per capita GDP.

As demonstrated in table 14.7, real GDP and real per capita GDP, foreign reserves, openness, and currency appreciation had a significantly positive impact on the amount of outward FDI. An examination of the relationship between the exchange rate of the Korean won and Korea's outward FDI shows weak correlation between them. In the case of Japan, its first period of rapid growth of outward FDI began in 1968, two years before the yen's appreciation in 1970. Its second period of rapid growth in FDI began in 1986, in the same year of the beginning of currency appreciation, but its FDI started to decrease in 1989 even though the yen reached its highest value in 1995. Thus, it would seem reasonable not to include currency depreciation as an explanatory variable. 
Regression results of the outward foreign direct investment flows of Japan (1965-2004) and Korea (1981-2004)

\begin{tabular}{lc}
\hline $\log (\mathrm{GDP})$ & 2.62109 \\
& $(0.31818)^{* * *}$ \\
$l_{1}$ (PGDP) & 0.42293 \\
& $(0.25037)^{*}$ \\
$l_{2}$ (PGDP) & 0.22870 \\
& $(0.35259)$ \\
$l_{3}$ (PGDP) & 0.29950 \\
& $(0.45017)$ \\
$R^{2}$ & 0.9948 \\
No. of observations & 64 \\
\hline
\end{tabular}

Note: Standard deviations are in parentheses.

*** Significant at the 1 percent level.

*Significant at the 10 percent level.

When the explanatory variables foreign reserves and openness were included in estimating the determinants of Japanese and South Korean FDI flows, the estimation results became unstable, perhaps due to the small sample size and the strong correlation among some of the explanatory variables. Thus, these two variables are excluded. That is, we include only real GDP and real per capita GDP as the regressors. To capture the upward jumps in Japan and Korea's outward FDI flows at the critical levels of economic development, we need a model in which the coefficient of real per capita GDP depends on which of the following four development levels the investing country found itself: ( 0 ) less than US\$ 8,500; (1) between US\$ 8,501 and US\$ 14,200; (2) between US\$ 14,201 and US\$ 17,000; and (3) greater than US\$ 17,001. More specifically, we estimate the following regression model with Japan and Korea's FDI flow data: ${ }^{30}$

$$
\begin{aligned}
\log \left(F_{i, t}\right)= & \beta_{1} \log \left(\mathrm{GDP}_{i, t}\right)+\gamma_{i}+\alpha_{1} \bullet l_{1}\left(\mathrm{PGDP}_{i, t}\right)+\alpha_{2} \bullet l_{2}\left(\mathrm{PGDP}_{i, t}\right) \\
& +\alpha_{3} \bullet l_{3}\left(\mathrm{PGDP}_{i, t}\right),
\end{aligned}
$$

where $F_{i, t}$ is the country $i$ 's FDI flow (measured at constant price) in time $t$, $\mathrm{GDP}_{i, t}$ is its real GDP (constant prices: chain series) in time $t, \gamma_{i}$ captures country $i$ 's fixed effects, $l_{l}\left(\mathrm{PGDP}_{i, t}\right)$ is the dummy variable for development level $l$.

The estimation results are given in table 14.8, which shows that the coefficient for real GDP was significantly positive, capturing not only the fact that Japan as a bigger country than Korea also invested more than Korea, but also that both countries invested more as they grew bigger, hold-

30. Japan's FDI stock statistics before 1980 are unavailable, making estimation of a similar model in FDI stock impossible. The UNCTAD database contains both flow and stock data from 1980, whereas data obtained from the Japan External Trade Organization (JETRO) contains only flow data beginning in 1965 . 
ing real per capita GDP as given. Among the three dummy variables, only that for development level 1 was significantly positive, implying that reaching the per capita real GDP of US $\$ 8,500$ had a statistically significantly positive impact on FDI flows.

If the determinants of outward FDI uncovered in the preceding sections are regarded as reliable, then they may be used as two different benchmarks with which to forecast the amount of Chinese FDI outflows in future years by incorporating the forecasts of China's explanatory variables. As stated in the preceding, it remains to be seen to whether the 2008 global financial and economic crisis led to a significant regime change for China's outward FDI.

\subsection{Host Economies, Sector Composition, and Geographical Distribution: A Comparison of China against Japan and South Korea}

We first analyze the determinants of the amounts of South Korea (19812006) and Japan's (1965-2004) FDI flows to their different host economies and compare them with the results for Chinese FDI as contained in table 14.5. The regression results for the gravity equation for South Korea and Japan are shown in tables 14.9 and 14.10 , respectively, with the coefficients for time dummies omitted. The common border variable was included for neither South Korea (which had common border only with North Korea, an adver-

Table 14.9 Regression results for recipient economies of South Korea's outward foreign direct investment (FDI) flows (1981-2006)

\begin{tabular}{lccc}
\hline & Full sample & $\begin{array}{c}\text { Tax haven economies } \\
\text { (OECD list) excluded }\end{array}$ & $\begin{array}{c}\text { Offshore financial } \\
\text { center economies } \\
\text { (IMF list) excluded }\end{array}$ \\
\hline $\log ($ GDP) & $0.62371^{* * *}$ & $0.67150^{* * *}$ & $0.73981^{* * *}$ \\
$\log ($ PGDP) & $(0.03920)$ & $(0.04056)$ & $(0.04269)$ \\
& -0.01846 & -0.04520 & $-0.15548^{* *}$ \\
$\log ($ dist $)$ & $(0.06349)$ & $(0.06353)$ & $(0.06894)$ \\
Landlock & $-0.46704^{* * *}$ & $-0.50343^{* * *}$ & $-0.30681^{* * *}$ \\
Island & $(0.08717)$ & $(0.08694)$ & $(0.09096)$ \\
$R^{2}$ & -0.21794 & -0.09816 & 0.16090 \\
No. of observations & $(0.19516)$ & $(0.19557)$ & $(0.20581)$ \\
\hline
\end{tabular}

Note: See table 14.5 notes.

aBecause Hong Kong, Macau, and Singapore appeared on the International Monetary Fund (IMF) list, and Taiwan had no FDI from China, the ChineseLang dummy became irrelevant for the sample that excluded offshore financial center economies.

***Significant at the 1 percent level.

**Significant at the 5 percent level. 
Regression results for recipient economies of Japan's outward foreign direct investment (FDI) flows (1965-2004)

\begin{tabular}{lccc}
\hline & Full sample & $\begin{array}{c}\text { Tax haven economies } \\
\text { (OECD list) excluded }\end{array}$ & $\begin{array}{c}\text { Offshore financial } \\
\text { center economies } \\
\text { (IMF list) excluded }\end{array}$ \\
\hline $\log$ (GDP) & $0.51785^{* * *}$ & $0.81830^{* * *}$ & $0.70191^{* * *}$ \\
$\log$ (PGDP) & $(0.02779)$ & $(0.02870)$ & $(0.03248)$ \\
& $0.32544^{* * *}$ & $0.50903^{* * *}$ & $0.09119^{*}$ \\
$\log ($ dist $)$ & $(0.04746)$ & $(0.04376)$ & $(0.05180)$ \\
& $-0.57466^{* * *}$ & $-0.82535^{* * *}$ & $-0.41346^{* * *}$ \\
Landlock & $(0.08402)$ & $(0.07441)$ & $(0.08847)$ \\
& -0.09821 & $0.69567^{* * *}$ & $-0.32926^{*}$ \\
Island & $(0.15794)$ & $(0.14201)$ & $(0.18778)$ \\
& $0.73837^{* * *}$ & $1.21364^{* * *}$ & $0.85247^{* * *}$ \\
$R^{2}$ & $(0.11771)$ & $(0.10806)$ & $(0.13322)$ \\
No. of observations & 0.2766 & 0.4515 & 0.3387 \\
\hline
\end{tabular}

Note: See table 14.5 notes.

${ }^{a}$ Because Hong Kong, Macau, and Singapore appeared on the International Monetary Fund (IMF) list, and Taiwan had no FDI from China, the ChineseLang dummy became irrelevant for the sample that excluded offshore financial center economies.

*** Significant at the 1 percent level.

*Significant at the 10 percent level.

sary during much of this period), nor Japan (which is an island economy that does not share any common border with any other country).

The results for China, South Korea, and Japan are similar in that their coefficients for GDP and distance had the same signs. The coefficient of per capita GDP was negative for both China and South Korea, but positive for Japan, probably reflecting the fact that Japan was a more advanced economy than both China and South Korea in the sample periods. Being a landlocked host economy was a disadvantage in attracting Chinese and Japanese FDI but not South Korean FDI. ${ }^{31}$ Finally, being an island economy had a significantly positive impact on attracting Japanese FDI, a less significantly positive impact on attracting South Korean FDI, and no impact on Chinese FDI.

Next, let's examine the sector composition of Japan and South Korea's FDI flows. Figures 14.4 and 14.5 illustrate the percentages of Japan and South Korea's outward FDI flows in different sectors, respectively. Before 1982, the mining sector was an important target of Japan's FDI, averaging about 20 percent. After that year, the sector's share fell to below 5 percent. South Korea's experience around 1990 was similar: before 1989, the share of investment in the mining sector was more than 10 percent, but it fell to 


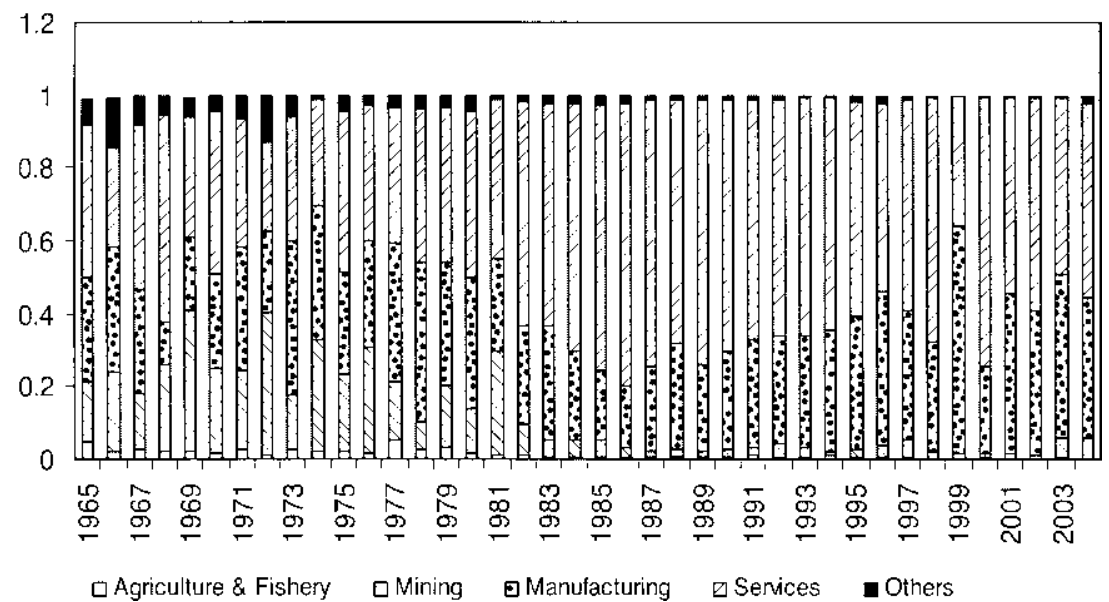

Fig. 14.4 Japan's sectoral distribution of outward FDI flows: 1965-2004 Source: JETRO.

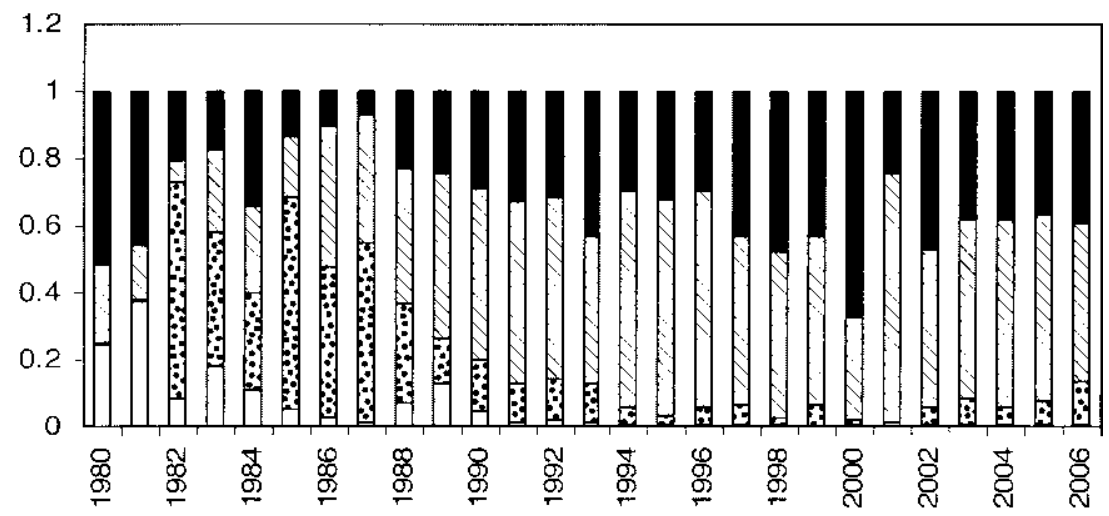

$\square$ Agriculture \& Fishery $\square$ Mining $\square$ Manufacturing $\mathbf{q}$ Senvices $\square$ Others

Fig. 14.5 Korea's sectoral distribution of outward FDI flow: 1980-2006 Source: Korea Eximbank.

Note: The figures for 1980 refer to cumulated outward FDI flows up to 1980.

about 5 percent by 1994. In contrast, the two countries' shares of investment in the services sector grew gradually over time. After 2000, Japan's share of investment in the services sector was about 50 percent, whereas South Korea's share was about 40 percent.

Notice that the decline of Japan's FDI in the mining sector occurred in its development stage 2 as defined in the previous section, whereas the decline of South Korea's FDI in the same sector occurred right from the beginning 
of its development stage 1. Also, South Korea's high share of FDI in the services sector occurred in its development stage 2, whereas Japan's high share of FDI in the same sector occurred long after it entered its development stage 3. That is to say, South Korea's sector composition followed similar changes as Japan's, but the pace of change was much faster, implying that there seemed to be less similarity in the two countries' evolution of their sector composition than in the evolution in their aggregate FDI outflows. A possible explanation is that South Korea's real per capita GDP reached Japan's level twenty years later, and the more globalized world economy by then could have required or permitted greater foreign investment in the services industries.

Let us compare China's sector composition of FDI flow with those of Japan and South Korea. In the following figures, we assume that investment in financial industries was one-sixth of the total FDI flows and stocks in 2003 to 2005 , more or less the ratio observed in 2006. On this assumption, during 2003 to 2006, China's average share of investment in the mining sector was 29.8 percent, which was higher than Japan and South Korea's historically high shares. Because China's present stage of economic development is similar to that of Japan in the 1960s and South Korea in the 1980s, China's investment in this sector may continue to grow until China's real per capita GDP reaches the range of US\$ $10,000 .{ }^{32}$ The average share of China's investment in the manufacturing sector during 2003 to 2006 was 12.4 percent, less than Japan in the 1960s and South Korea in the 1980s. Thus, its share in investment in the manufacturing sector may grow further.

Making the same assumption about the shares of FDI in finance during 2003 to 2005, we see that China's investment in the services sector during 2003 to 2006 averaged at 55.5 percent, which was significantly higher than that of Japan and South Korea in the 2000s. Judged against the experiences of Japan and South Korea, it seems curious why China's investment share in the services sector was so high, even after account is taken of the fact that the world economy in the twenty-first century was more services-oriented than in the last century. One may speculate that it was a result of China's capital control policy, which induced Chinese firms to invest in offshore financial centers before they were reinvested elsewhere in other nonservice-related sectors (including "round-tripping" FDI back to China). Perhaps the fact that most of the Chinese investors were SOEs was another reason because they might have an incentive to hide their identity and destination of investment through companies set up in the tax havens. If Japan and South Korea's sector compositions in outward FDI had predictive value for China's, however, then China's investment share in the services sector may decline over time in response to China's increasing liberalization of its capital accounts and as a result of increases in the shares of mining and manufacturing. 


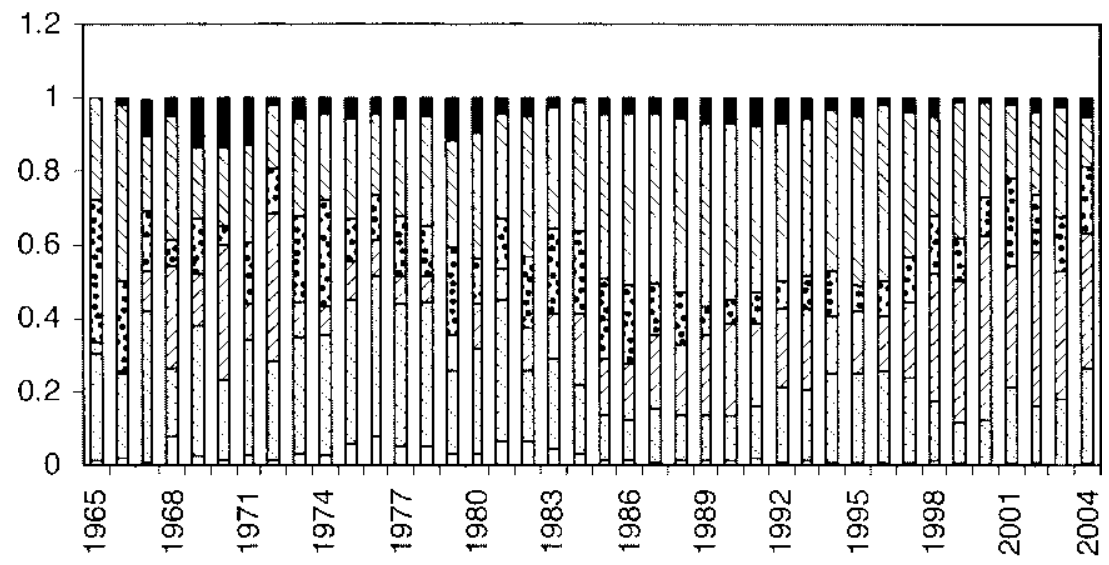

$\square$ Africa $\square$ Asia $\square$ Europe $\$$ Latin America $\square$ North America $\square$ Oceania

Fig. 14.6 Japan's regional distribution of outward FDI flow: 1965-2004 Source: JETRO.

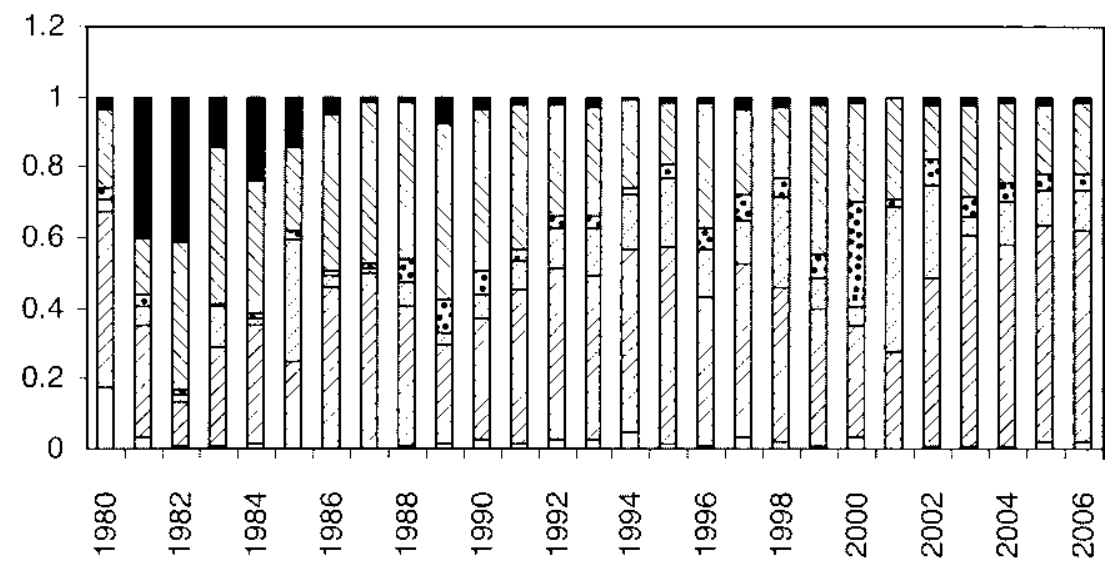

$\square$ Africa $\square$ Asia $\square$ Europe $\square$ Latin America $\square$ North America $\square$ Oceania

Fig. 14.7 Korea's regional distribution of outward FDI flow: 1980-2006 Source: Korea Eximbank.

Note: The figures for 1980 refer to cumulated outward FDI flows up to 1980.

Figures 14.6 and 14.7 depict the shares of Japan and South Korea's FDI flow to different regions. A comparison of these figures against those for China contained in table 14.3 indicates that the share of China's outward FDI flow to Asia in 2003 to 2005 was broadly similar to those of Japan in 1960s and South Korea in 1980s. However, China's shares of investment 
flows to Europe and North America in the same years were much lower than those of Japan and South Korea's in their respective comparable periods. In contrast, China's share of investment flow to Latin America was abnormally higher than Japan and South Korea's due to China's huge investment in tax havens in Latin America.

Japan's average FDI share in Africa from 1965 to 1985 was 3.6 percent, equal to that of China during 2003 to 2006. However, Japan's share declined significantly after 1985 and reached a negligible 0.3 percent by 2004. Compared with Japan, South Korea's FDI share in Africa was relatively low in the entire period. During 1990 to 1998, its average share was about 2.3 percent. Its African share began to decrease after 1998, and by 2004, it dropped to 0.85 percent, which was less than China's current share. Given Africa's much greater political importance to China than to Japan and South Korea, China's future African shares could easily be much higher than the current shares of Japan and South Korea.

\subsection{Summary and Direction of Further Research}

In this paper, after briefly describing China's "go overseas" policy, we have provided a systematic analysis of the size and composition of China's outward FDI in 2003 to 2006, using data provided by China's Ministry of Commerce. In addition, we made an attempt to uncover the determinants of the direction and amount of China's outward FDI and briefly described China's foreign direct investment and other forms of overseas cooperation in the energy sector. Finally, we also attempted to understand the determinants of the world's source economies' outward FDI and, in particular, those of Japan and South Korea, in order to provide benchmarks for China's past and future outward FDI.

Our empirical analysis of the destination of China's FDI reveals that the real GDP of host economies had a positive impact on the amounts of Chinese FDI flows to and FDI stocks in them. Their real per capita GDP had no impact on FDI flows but a negative impact on FDI stocks. Their distance from China, sharing a common border and speaking the same language, had the expected impact. The empirical analysis of the world's source economies reveals that real GDP, real per capita GDP, foreign reserves, currency appreciation, and time trend all had a significantly positive impact on their aggregate outward FDI flows and stocks.

One direction of further research is the use of the experience of the world's leading source economies, in particular Japan, South Korea, and major emerging economies such as Brazil, Russia, and India to forecast China's outward FDI in the future. 


\section{References}

Antkiewicz, Agata, and John Whalley. 2006. Recent Chinese buyout activity and the implications for global architecture. NBER Working Paper no. 12072. Cambridge, MA: National Bureau of Economic Research, March.

Cai, Kevin G. 1999. Outward foreign direct investment: A novel dimension of China's integration into the regional and global economy. China Quarterly 160:856-80.

Cheung, Yin-Wong, and Xing Wang Qian. 2009. Empirics of China's outward direct investment. Pacific Economic Review 14 (3): 312-41.

Child, John, and Suzana B. Rodrigues. 2005. The internationalization of Chinese firms: A case for theoretical extension? Management and Organization Review 1 (3): $381-410$.

Deng, Ping. 2004. Outward investment by Chinese MNCs: Motivations and implications. Business Horizons 47 (3): 8-16.

Hong, Eunsuk, and Laixiang Sun. 2004. Go overseas via direct investment: Internationalization strategy of Chinese corporations in a comparative prism. Working Paper. University of London, Centre for Financial and Management Studies. School of Oriental and African Studies.

Ministry of Commerce. 2004-07. Statistical bulletin of China's outward foreign direct investment 2003-2006 (in Chinese). Beijing: Ministry of Commerce.

Taylor, Ian. 2009. China's new role in Africa, 37-63. Boulder, Colorado: Lynne Rienner.

Zweig, David. 2006. "Resource Diplomacy" under hegemony: The sources of SinoAmerican competition in the 21st century? Working Paper no. 18. Center on China's Transnational Relations, Hong Kong University of Science and Technology, Hong Kong.

\section{Comment Nicholas Lardy}

The analysis of Leonard K. Cheng and Zihui Ma is an important addition to our understanding of the nature of China's outbound foreign direct investment (FDI). While outbound FDI from China has grown substantially in recent years, it remains far smaller than inward investment flows, and most of the existing literature focuses on the latter.

One strength of the analysis of Cheng and Ma is that it relies on FDI data that are compiled in accordance with Organization for Economic Cooperation and Development (OECD) definitions and International Monetary Fund (IMF) balance of payments guidelines. This is a much more realistic approach than the all too prevalent practice of relying on a compilation of press reports. Press accounts fail to differentiate between proposed projects and actual flows, fail to recognize that flows for those projects that are undertaken frequently occur over a period of years, and fail to differentiate between projects financed with Chinese direct investment from those financed with loans from Chinese financial institutions.

Nicholas Lardy is a senior fellow at the Peterson Institute for International Economics. 